\title{
A STUDIES ON BENTHIC FAUNA OF AMRAVATI DISTRICT (M.S)
}

\author{
C. B. Meshram \\ Shri shivaji science college, Amravati, (M.S), India. \\ Corresponding author Email : cbmeshram53@gmail.com
}

\begin{abstract}
:
Aquatic macro invertebrate plays significant role in responding to a variety of environmental conditions and therefore may be used as bio indicators for water quality assessment .Macro benthic fauna is responsible for efficient utilization of sediment and their diversity indicates health of a wetland in accordance to its sediment quality..The use of studying macro invertebrates as it gives fare idea about the functioning of the system besides assessing its trophic status. Physico chemical parameters and macro invertebrates fauna of selected upland (Khatijapur reservoir) and low land (Upper Wardha Project ) of Amravati district, Maharashtra, India were studied from march,2011 to Febuary,2012. Surface water and benthic samples were collected from two sampling site from each basin. Physico- chemical studies revealed that Upper Wardha reservoir shows higher trophic level. Considerable variations in benthic fauna have been recorded in both the water bodies. The macro invertebrates were represented by four classes belonging to Annelida, Mollusca, crustacean and from Insecta. Khatijapur basin is poor in terms of species richness as compare to Upper Wardha Project. The dominance of Macro organism in both the water bodies recorded in the order Mollusca > Insecta > oligochaeta > Crustacea.
\end{abstract}

\section{Keywords:}

Water quality ,benthic fauna, Khatijapur reservoir, Upper Wardha project, Trophic status.

\section{Introduction:}

Macro invertebrates can serve as excellent diagnostic indicators for measuring the extent of pollution of aquatic ecosystem. The low number of species and density of benthic life is attributed to low bottom oxygen (Moore,1942). Welcome (1979).Stresses on the combination of factors like temperature, dissolved oxygen ,nature of substratum, grazing and predation etc., as major factors for the growth of benthic faunal community. The distribution , composition and abundance of benthic fauna are biological indicator of water and sediment quality and trophic status at the soil water interface (Pandey 
et.al,1983 ; Anthony, 2001; Garg et al.,2009; Edokpayi et al., 2010 ). Benthic fauna plays an important link in the energy flow from primary producers to fish (Olah,1976). The study on macro invertebrates are due to Michel (1968), Mandal and Moitra (1975). Similar studies were conducted on lakes in and around Hyderabad, Andhra Pradesh (Anitha et,al.2004; Rao, 2006). Literature reviewing on this aspect showed an inadequate information in the water bodies at Vidarbha in Maharashtra and Amravati district in Particular. From this point of view, observations on the benthic diversity in relation to water parameters have been presented in this paper.

\section{Material and Method:}

Study area The study was conducted on upland Khatijapur reservoir which is located at high altitude in ranges of Satpuda Hills of Melghat area, it is located at latitude $210-16^{\prime \prime}-30^{\prime \prime \prime \prime}$ and at longitude $770-2.4^{\prime \prime}-00^{\prime \prime \prime \prime}$ and it is found at 360.50 MSL. Similarly on the low land newly constructed Upper Wardha project is also called " Naldamyanti dam " located at $306 \mathrm{MSL}$ and at latitude 210-16"-18"' N and at longitude 780- 03"-27"'E in the district- Amravati (Maharashtra). The study was conducted during March, 2011 to February, 2012. Samples from the Two stations were collected at monthly intervals at fixed sampling sites. Water quality parameters were analyzed as per Standard methods (APHA,1998). Soil samples were sorted out in the laboratory with the help of brush and preserved in 5\% formalin. For qualitative analysis of benthos standard key were used (Subba Rao, 1989). They were identified following Ward and Whipple (1992), Needham and Needham (1962), Tonapi (1980), Adoni (1985) and Pennak (1989). The identification is based on mainly the shell characters described earlier (Preston,1915; Satyamurthi, 1960). For qualitative analysis number of benthos per unit area were calculated as follows. Benthos No./m2 = N / A X 104 Where $\mathrm{N}=$ Number of Organism per sample $\mathrm{A}=$ Biting area of sampler (15 $\mathrm{x} 15 \mathrm{~cm})$. 


\section{Result and Discussion:}

Physico - chemical parameters In the present study abiotic factors of upland reservoir (Khatijapur basin) and, lowland reservoir (Upper Wardha Project) given in table -1 . The physicochemical parameters tested in both the basins are water temperature, $\mathrm{pH}$, Total Alkalinity, Dissolved Oxygen, Free co2, Hardness, Total dissolved solid, Chloride, and Nitrates. The water temperature of upland and lower basin fluctuated from 20.60c - 33.00c , and 21.800c $32.400 \mathrm{c}$. The reported temperature was closely followed the atmospheric temperature $(210 c-33.400 c)$. Seasonal variations recorded for these water bodies revealed low water temperature was observed in winter and maximum water temperature was recorded during summer months. This may be attributed to high cold and lower photoperiod in winter, while maxima in water temperature in summer season may cause due to evaporative loss, water shrinkage and high sunshine. (Bhowmik ,1988). The pH was fluctuated 6.17 8.0 in upland and $6.05-7.40$ of low land reservoir. Total Alkalinity was in the range from $110 \mathrm{mg} / 1$ to $210 \mathrm{mg} / 1$ and $150 \mathrm{mg} / 1$ to $330 \mathrm{mg} / 1$ respectively. High values of alkalinity was due to the presence of salt generated through the death and decay of the macrophytes and other aquatic organisms,(Sugunan et al.,2000).The Dissolved oxygen was within moderate range $7.1 \mathrm{mg} / 1$ to $11.8 \mathrm{mg} / 1$ and $6,10 \mathrm{mg} / 1$ to $8.30 \mathrm{mg} / 1$ respectively, which is an indication of good water quality ( Surve et al., 2004). Free co2 was absent in few month during study, however lowland showed more fluctuation in variable months and was observed in the range from $00 \mathrm{mg} / 1$ to $6.00 \mathrm{mg} / 1$ it may due to the respiratory mechanism of biotic community (Garg,2010). Total hardness calculate in both the water bodies was moderate and found in between $94.0 \mathrm{mg} / 1$ to $232.0 \mathrm{mg} / 1$ in Khatijapur (Upland) and $86.0 \mathrm{mg} / 1$ to $210.0 \mathrm{mg} / 1$ in low land reservoir (Upper Wardha Project). Mean values of Total dissolved solid in upland and lowland reservoir was more or less similar but high values associate with upland $315.71 \mathrm{mg} / 1$ as compare to low land $260.00 \mathrm{mg} / 1$. Chlorides in water is not utilized for the plant growth and their pressure in 
large quantity is regarded as an indicator of organic pollution. The chloride content in both water was found in permissible limit, and was seen lower $14.02 \mathrm{mg} / 1$ and $74.08 \mathrm{mg} / 1$ in up and low basin respectively. Nitrate content of the water in upland and lowland reservoirs are within permissible limit and no definite trends in the fluctuation occurred during the period of investigation. The nitrate contents was observed $0.52 \mathrm{mg} / 1$ and $0.43 \mathrm{mg} / 1$ respectively at whole investigation of respective reservoirs, however, higher values were recorded during rainy season. It is due to surface runoff from agriculture field (Thilaga,2005). The lower nitrates values can be attributed to their utilization by the phytoplankton"s. Benthic Fauna The diversity and seasonal changes in benthic fauna have been studied on the basis of collection obtained from monthly survey for a period of one year. The organisms were identified species wise and their abundance were calculated as numbers per square meter following Jhingran et al., (1969). The identification is based mainly on the shell characters as proposed earlier (Blanford Godwin-Austin, 1908;

Satyamurthi,1960). Molluscs Molluscs exhibited predominant over insect, oligochaetes and crustacea in the investigation carried out on both upland and lowland reservoirs. On comparing both the basins lower reservoir was rich in terms of density and diversity. Site III was most habituated by molluscan dominance followed by site I, site IV and site II. respectively ( Table-2). Dominanance of mollusca in both the reservoirs can be attributed to organically rich bottom, alkaline water and organically rich sediments. During present investigation a total of 31 species were recorded. Out of 31 species Mollusca and Insecta represented by 13 species each followed by 3 oligochaete and 2 species of crustacean (Table-2). Site III encounter more species number as compared to site I < IV < II. In both the reservoir maximum benthic fauna appeared at shallower region where macrophytes are more which might have provide good habitat as well as food for the better growth. The dominance of benthic fauna (Table-3, Fig-1 \& 2) for both the basins was in the order of Mollusca $>$ Insecta $>$ Oligochaeta $>$ Crustacean Amongst the molluscan species 
observed some species are common to all sites and few of them did not show their appearance at some stations. Melanoides tuberculata located at both the basins have proved some medicinal values (Thompson, 1984 ; Dundee and Paine, 1999). But their was no definite pattern in the population density of other benthic fauna. Insecta From the class Insecta lower basin have qualitatively and quantitatively more numbers than the upper reservoir. Among insects dragon flies, aquatic bugs, cybister sp, mosquito and chironomus larvae dominated in both the reservoirs confirming eutrophication nature. Relatively low dissolved Oxygen contributes more population of larval forms. Oligochaeta Oligochaeta comprises of Tubifex ,Limnodrillus and pheretima species. Tubifex signifies higher tropics level in both the basins which favor vegetation for their growth (Aydin,2005). Crustacean Crustacean represented only by crabs and Palemone species. They were observed at site I and site III in abundance as compared to site II and site IV in both the basins. The structure composition and abundance of benthic community in both the wetlands are due to human activities, eutrophication and organic pollution (Pamplin et al., 2006).

\section{Conclusion:}

Present study indicates the aquatic vegetation plays significant role for the growth and distribution of all benthic population. Diversity and density of benthic community reflect eutrophication and organic pollution of these basin, however, some more studies are required to establish the importance of various environmental factors that produce collective effect on the distribution of fresh water macro invertebrates.

\section{Reference:}

Adoni,,A.D .(1985): Work book on Limnology, Pratibha Publishers C-10, Gour Nagar,Sagar-470003,India.216. 
Anitha,G.,Kodarkar,M.S,Chandrashekhar,S.V.A and Nalini (2004): Studies on macro benthos in Mir alam Lake, Hyderabad,(A.P). J. Aquatic Biology. 19:61-68.

Anthony,E.O. (2001): Composition and diversity of Diptera in temporary pond in Southern Nigeria. Tropical Ecology. 42(2):259-268.

APHA (1998) Standard Methods for the examination of water and waste water.20th Ed. American Public Health Association, Washington, New York.

Aydin,H, (2005): The Oligochaeta (Annelida) Fauna of Top Dam-Lake, Turkish Journal of Zoology, 30,pp. 83-89.

Bhowmic, M.L. (1988): Environmental factors affecting fish food in fresh water fisheries, Kalyani,W.B,India,Ph.D thesis,(unpublished) University of Kalyani.pp.238.

Blanford,W.T. and Godwin-Austen,H.H. (1908) : Fauna of British India Series,I. (Mollusca - Testacellidae and Zonitidae). Dundee,D.S and A.Paine (1999) : Ecology of the snail,Meanoides tuberculata (Muller), intermediate host of human liver fluke (Ophisthorchis sinensis) in New Orlcans, Louisiana. Nautilus. 91 (1).pp.17-20.

Edmondson,W.T.(1992): Fresh Water Biology, International Books \& periodicals Supply Services, New Delhi.

Edokpayi,C.A.,Aveez,O.,Olowoporoku and E. Uwadiae, (2010): The hydrochemistry and benthic fauna characteristics of an Urban drinking creek. Inter.J.Biodiver.Conser.2,196-203.

Garg, R.K., Rao, R.J. and Saxena,D.N.(2009): Correlation of molluscan diversity with physic chemical characteristics of water of Ramsar reservoir, India. Int. J. Biodiversity Conservation, 1 (6),October, pp.202-207. 
Jhingran,V.G,Natrarajan,A.V, Banerjee,S.M and David, A. (1969) : Methodology on reservoir fisheries investigation in India. Central Islands Fisheries Research Institute: Bulletin No.12 : 109.

Mandal,B.K. and Moitra,S.K.(1975): Studies on the bottam fauna of freshwater fish pond at Burdwan. J.Inland,Fish.Soc.India. VII:43-48.

Michel,R.G. (1968): Studies on bottom fauna in a tropical freshwater fish pond. Hydrobiologia.31: 203-230.

Moore,W.G.(1942): Field studies on oxygen requirement of fresh water fishes.Ecology.23: 317-324.

Needham,J.G.and Needham, P.R. (1962): Freshwater Biology. Holder Day Inc.San.Francisco. Olah,J (1976): Energy transformation by Tanypus punctipennis Meigh, (Chironomidae) in lake Balaton. Annal.Biol.Tihany.43: 88-92.

Pamplin,P.A.Z, Almeida, T.C.M and Rocha,O (2006) : Composition and distribution of benthic macroinvertebrates in Americana reservoir (SP ,Brazil). Acta Limnol.Bras. 18(2):pp. 121-132.

Pandey,K., Radheyshyam,Prasad,S and Chaudhary,H.S. (1983): A study on macrozoo benthos and physic chemical characteristics of the bottom of Bakhira Lake,U.P,India,Int.Rev.Ces.Hydrobiol.68(4):591-597.

Pennak, R.W.( 1989): Freshwater Invertebrates of United States (ProtozoaMollusca) 3rd Edition. A Wiley Interscience Publication.

John Wiley and Sons, Inc.628. Preston,H.B. (1915): Fauna of British India Series. (Freshwater Gastropods and Pelcypoda).

Rao,R.S.(2006): Studies on macro invertebrates in Banjara Lake, Hydrabad,A.P, India Ph .D thesis, Osmania University, Hyderabad. 
Satyamurthi,S.T. (1960): The land of freshwater Molluscs in the collection of the Madras Government Museum. Bull Madr.Govt.Mus. (Nat.Hist.Series) 6(4): 1-174 with 24 plates.

Subba Rao, N.V.(1989): Hand Book of Freshwater Molluscs of India,ZSI.Calcutta,pp-289.

Sugunan,V.V;G.K.Bhattacharya,B.K and Hassan, M.A (2000): Ecology and Fisheries of bills in West Bengal. Bull.No.103: Cent. Island Dish. Res. Inst.pp.53

Surve,P.R.,Ambhore,N.E. and Pulle,J.S. (2004): Seasonal variation of physic chemical characteristics of Sonkhed dam. J.Comp.Toxicol.Physiol.Vol.1 (3): 147-153.

Thilaga,A.,Subhasini,S. and Kumar, K.L.(2005): Studies on nutrient content of the Ooty Lake with reference to pollution. Nat.Env.Poll.Tech.4:299-302.

Tonapi,G.T. (1980): Freshwater animals of India (An ecological approach). Oxford and IBH Co., New Delhi, pp-319 +XVII. Thomson,F.G.(1984) : Field guide to the Freshwater Snails of Florida, Florida Museum of Natural History. 289 pp.

Ward,H.B.and Whioole,G.C.(1992 Freshwater Biology (2nd Ed). Indian reprint, International Books and Periodically supply service,New Delhi. Pp.1247. 